\title{
Observation of a Severe Wind Case Caused by Gust Front and Its Boundary Layer Structures Characteristics
}

\author{
Changyi $\mathrm{Xu}^{1}$ and $\quad$ Yan Wang ${ }^{2 *}$ \\ ${ }^{1}$ Binhai New Area Meteorological Office of Tianjin, Tianjin 300457, China \\ ${ }^{2}$ Tianjin Weather Modification Office, Tianjin 300074, China
}

\begin{abstract}
Based on Doppler radar 3D-composited reflectivity, wind profiler radar, boundary layer Tianjin tower of $255 \mathrm{~m}$ as well as intensified automatic surface observation data, the evolution of the boundary layer associated with two successive gust front processes in the evening of 10 June 2016 and the intensity of the related disastrous surface high wind were analyzed. The results shown as follows: (1) To the same storm cell, the wind intensity caused by the outflow boundary in the main body was stronger than the wind caused by the gust front. The intensity of the disastrous high wind was related to the maximum descending velocity in the boundary layer and the associated height. The stronger the maximum descending velocity and the lower the level, the stronger the disastrous high wind was. (2) The tower data indicated, as the approaching of the gust front, convergence fluctuations first emerged at $\operatorname{low}(20 \mathrm{~m})$ and middle $(120 \mathrm{~m})$ levels of the tower, leading the emergence of disastrous high wind by 8 minutes. When the gust front passed over, the maximum variations of cooling and the wind velocity were in pace with each other.
\end{abstract}

\section{Introduction}

The meso-scale boundary, i.e. gust front or outflow boundary, is formed at the interface between the sinking cold air that reaches low level in the convective storm and the warm wet air at low level. During its passage, the temperature drops, the pressure jumps, and the wind direction shifts. The gust front is actually the boudary between sinking cold air inside the convection and the warm environmental air near the storm. Except elevated convection, the factors that determine local emerging and developing of the convective storm are in the boundary layer, while the gust front is one of the major types of the convergence lines in the boundary layer. Surface divergence(convergence) is obvious behind (before)the gust front, and obvious updraft is observed near the gust front $^{[1,2]}$.

In recent years, studies on the structures of gust front and the related initiation mechanisms using intensified automatic surface observation data and Doppler radar data increased. Wu et al. [3] analyzed the evolution characteristics of the gust front and the high wind behind it, pointed out that strong rear inflow favored stronger sinking in the rear storms, and then produced stronger downburst and gust front in the surface. Additionally, strong convective cells emerged when two gust fronts moved heading toward each other ${ }^{[4]}$.

Primary studies on the relationship between cold gust velocity and descending speed had many results. However, the relevance between the descending speed of

\footnotetext{
* Corresponding author: swallownx@163.com
}

the gust accompanied by the gust front in the boundary layer and the instantaneous high wind was less studied. The fine resolution data, such as the Doppler radar data ${ }^{[5,6]}$, wind profiler radar data ${ }^{[7]}$ and the tower data in boundary layer ${ }^{[8,9]}$, are important to have detailed and quantitative investigations on the related issues in the boundary layer. Utilizing the multi-data in the boundary layer of wind profiler radar data, the meteorological boundary layer tower data and the intensified automatic surface observation data, combined with 3D-composited reflectivity fields based on the four Doppler radars, a disastrous high wind caused by a quasi-line meso-scale convective system on 10 June 2016 was studied. The relationship between the downdraft speed of the surface high wind caused by the gust front in the boundary layer and the instantaneous high wind was investigated to reveal the vertical structures of meteorological elements in the boundary layer accompanied with high wind, and will help to improve the forecasting and warning for the intensity of the surface high wind induced by the gust front.

\section{Weather state and environmental conditions}

\subsection{Case description}

In the evening of 10 June 2016, a wide range of thunderstorm high wind emerged in 
Beijing-Tianjin-Hebei region, the maximum velocity reaching 10 grade $\left(26.0 \mathrm{~m} \cdot \mathrm{s}^{-1}\right)$ appeared in Qingxian Hebei province. Figure 1 shown the distribution of national automatic stations in Beijing-Tianjin-Hebei region where the real state of wind speed $\geqslant 17.0 \mathrm{~m} \cdot \mathrm{s}^{-1}$ from 14:00 10 June to 02:00(Beijing time without special instructions) 11 June, and the velocity as well as the time with instantaneous wind speed $\geqslant 9 \operatorname{grade}\left(20.8 \mathrm{~m} \bullet \mathrm{s}^{-1}\right)$ were indicated in the figure.

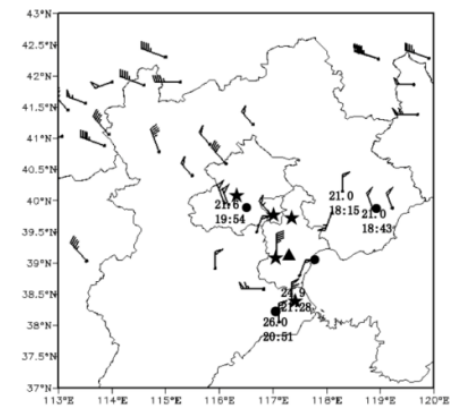

Fig.1. High wind in Beijing-Tianjin-Hebin region from 14:00 BJT 10 June 2016 to 02:00 BJT 11 June 2016( $\star$ indicate the location of the wind profiler radar, indicate the location of the Doppler radar, $\boldsymbol{\Delta}$ indicate the location of Tianjin tower)

\subsection{Synoptic background}

The Mongolia cold vortex maintained at 08:00 10 June 2016(figure omitted) and Beijing-Tianjin-Hebei region was to the southeast of the cold vortex. The quasi-line convective system initiated over the border in head of the warm center and to the front left of the southwest low level jet at $850 \mathrm{hPa}$ (figure omitted). The cold-dry air intruded at middle level was over the low level warm-wet air which led the temperature differences between $850 \mathrm{hPa}$ and $500 \mathrm{hPa}$ to exceed $28^{\circ} \mathrm{C}$. It indicated that the structure with cold-dry air at high level and warm-wet air at low level was obvious, increasing static instability. Cyclonic vortex occurred in southern part of Hebei at 14:00 on surface chart(figure omitted), accompanied by the strong warm wet center which produced a belt of large temperature gradient with the cold center in eastern Tianjin, benefited the development of the storm.

\subsection{Environmental conditions}

The data of Beijing radiosonde station at 08:00 10 June indicated that $850-1000 \mathrm{hPa}$ was the wet level and $800-500 \mathrm{hPa}$ was the dry level. The greater the value the drier the air was or the thicker the dry level was, favoring the intense downdraft inside the storm ${ }^{[10]}$. The intensity of dry air was $20^{\circ} \mathrm{C}$ at mid-high troposphere, the dry level was clear. DCAPE (commenced at $600 \mathrm{hPa}$ ) reached $1153.9 \mathrm{~J} \cdot \mathrm{kg}^{-1}$ with great potential associated with severe downdraft and high wind. CAPE increased from 365 $\mathrm{J} \bullet \mathrm{kg}-1$ at $08: 00$ to $2179 \mathrm{~J}_{\mathrm{kg}^{-1}}$ at 14:00. Both the amplification of CAPE and the CAPE at 14:00 were big, leading the development of instable convective system. The temperature difference between $850 \mathrm{hPa}$ and $500 \mathrm{hPa}$ was used to stand for the static stability and it reached $27^{\circ} \mathrm{C}$ at 08:00 10 June. The vertical shear was $22.8 \mathrm{~m} \cdot \mathrm{s}^{-1}$ in 0-6km at 08:00 10 June typed as a severe vertical shear [11].

\section{The evolution characteristics of the gust front}

The ' 6.10 ' disastrous high wind in Tianjin and southern Hebei were affected by two gust fronts in sequence. The first gust front (marked as gust front 1) emerged at 15:42 in Daxing, Fangshan of Beijing, and disappeared around Huanghua, Haixing of southeastern Hebei at 21:12. The second gust front (marked as gust front 2) arose at 20:24 in Hejian of Hebei province, and disappeared around Yangxin, Binzhou of Shandong province. Based on the maximum velocities caused by the gust front measured by automatic stations, the life of the gust front can be divided into three stages: the evolution stage, the mature stage and the dissipating stage.

\subsection{Gust front 1}

\subsubsection{The evolution stage (15:42-17:30)}

The convective storm cell moved into the adjacent area of Beijing-Tianjin-Hebei region at 16:36 10 June, the structure of the convective system was similar to the individual cells(CCs) ${ }^{[12]}$. Surface convergence line formed by the northeasterly and southwesterly was to the southwest of the convective cell. According to the radar reflectivity at low elevation angles, to the south of the cell existed a narrow bow echo which denoted the gust front 1 with the maximum wind speed up to $14.9 \mathrm{~m} \bullet \mathrm{s}^{-1}$ at 16:04. The Position of surface convergence line detected by every $5 \mathrm{~min}$ surface wind direction observation agreed with the positon observed by radar echo, confirming the exact position of the gust front. The adjacent area of Beijing and Tianjin was affected by convective cell at 17:00, forming cold pool (surface temperature 20-23 ${ }^{\circ} \mathrm{C}$ ), temperature decreased at $6^{\circ} \mathrm{C} \cdot(10 \mathrm{~min})^{-1}$ near the high wind areas. Most part of Tianjin was controlled by high temperatures greater than $31^{\circ} \mathrm{C}$.Based on the wind distribution, the gust front produced by the convergence of cold pool outflow and environmental southeasterly was associated with surface convergence line and weak narrow echo. Additionally, a convergence line of southwesterly and southeasterly was in northeastern Tianjin. In terms of the distribution of temperature and dew-point temperature, this convergence line corresponded with the gradient between cold-wet and warm-dry air, which was known as sea-breeze front(Figure 2a).

Boundary layer wind could be analyzed in detail through wind profiler radar data with high spatial and temporal resolutions. Gust front 1 began to influence the border of Beijing and Tianjin at 15:30 with wind speed lower that $8 \mathrm{~m} \cdot \mathrm{s}^{-1}$ in the boundary layer and ascending movement under $700 \mathrm{~m}$. At 15:48, the boundary layer was dominated by descending air. After the gust front passed, convergence fluctuation arose under $700 \mathrm{~m}$ (figure omitted).At 16:18, the maximum downdraft velocity 
reached $0.5 \mathrm{~m} \bullet \mathrm{s}^{-1}$ and high wind appeared in Xianghe station 7 minutes later.
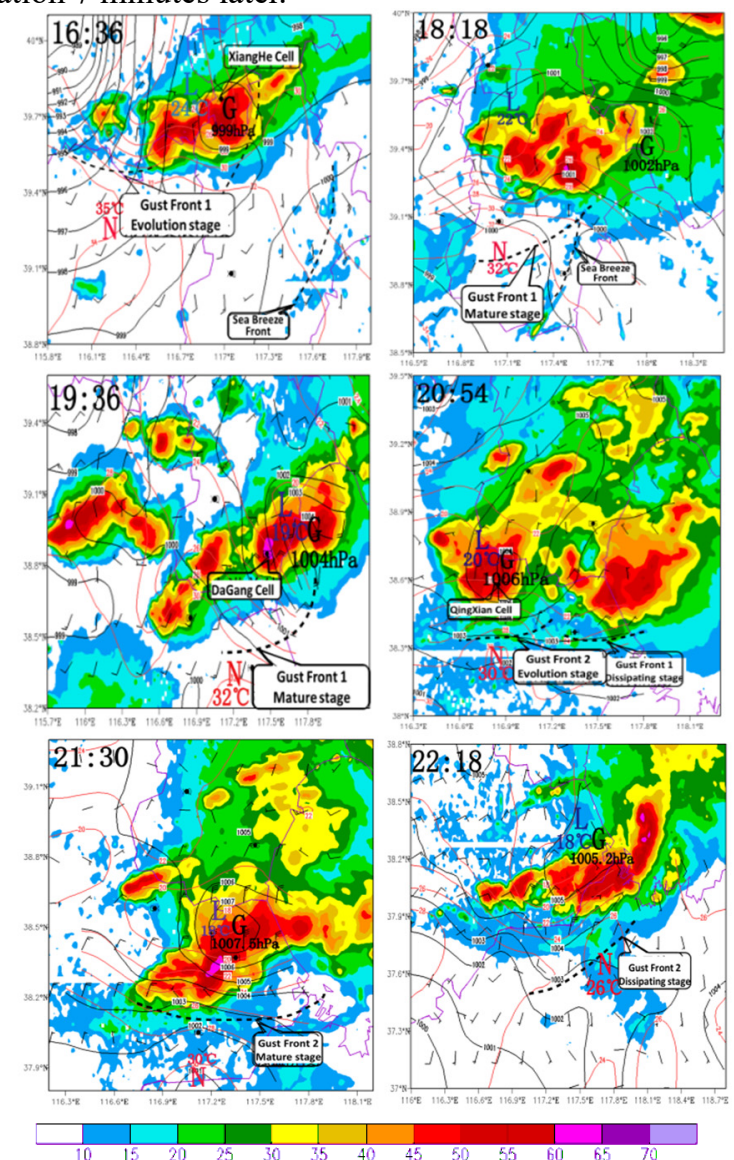

Fig.2. Composite reflectivity of convective systems(shading, units:dBZ), surface temperature (red isolines, units: ${ }^{\circ} \mathrm{C}$ ), surface pressure(black contours, unit:hPa) and surface wind from ground-based automatic stations on 10 June 2016. XH is the abbreviation of Xianghe, LF: Langfang, XQ : Xiqing, DG:Dagang, QX:Qingxian, HH: Huanghua, MC:Mengcun (black dashed lines: meso-scale surface convergence line, G: the center of thunderstorm high, N: warm center, L:cold center)

\subsubsection{The mature stage (17:30-20:00)}

At 17:30, the convective system was the broken lines (BLs) structure ${ }^{[12]}$, the surface temperature and pressure gradients became intenser associated with gust front 1 in the head of the storm cell. This was the strongest period of gust front 1 when the temperature gradient along the front was $2.7{ }^{\circ} \mathrm{C} \cdot(10 \mathrm{~km})^{-1}$ and the pressure gradient reached $8.8 \mathrm{hPa} \bullet(10 \mathrm{~km})^{-1}$. At $18: 18$, the convective cell moved southeastward, the cold pool advanced southeastward, and the surface temperature dropped to 22-24 ${ }^{\circ} \mathrm{C}$. The high temperature center weakened comparing to the one at 17:00. Wind propagated southeastward accompanied by the gust front. At 18:18, the gust front met the westward sea-breeze front in Dongli Tianjin, intensified into a stronger convergence belt which was coincidence with the simulation results of Wang et al. ${ }^{[13]}$. The gust front brought 7 grade high wind of $17.0 \mathrm{~m} \cdot \mathrm{s}^{-1}$ in Xiqing. Strong updraft emerged in the boundary layer and lower troposphere, triggered convective cell, and caused the convective cell to grow rapidly.
According to the horizontal wind profiler radar data in Xiqing (figure omitted), when gust front 1 passed, the environmental wind was dominated by warm-wet southwesterly of $8-12 \mathrm{~m} \cdot \mathrm{s}^{-1}$, stronger than in the evolution stage. Ascending movements were in the boundary layer and lower troposphere above $870 \mathrm{~m}$, whose maximum value was up to $1.0 \mathrm{~m} \cdot \mathrm{s}^{-1}$ around 2.3 $\mathrm{km}$. During this stage, the horizontal and vertical velocity were stronger than in the first stage in the boundary layer and lower troposphere when the gust front passed by.

\subsubsection{The dissipating stage (20:00-21:12)}

After 20:00, the maximum wind speed associated with gust front 1 decreased to $16.2 \mathrm{~m} \cdot \mathrm{s}^{-1}$. And the temperature gradient and pressure gradient along the gust front reduced to $1.2{ }^{\circ} \mathrm{C} \cdot(10 \mathrm{~km})^{-1}$ and $2.0 \mathrm{hPa} \cdot(10 \mathrm{~km})^{-1}$, respectively. With the horizontal wind profiler radar data in Huanghua, the gust front was in the dissipating stage, strong convergence fluctuation occurred under $1.5 \mathrm{~km}$ in the boundary layer, the wind maximum larger than 22 $\mathrm{m} \cdot \mathrm{s}^{-1}$ was around $0.8-1.4 \mathrm{~km}$. Accompanied by the passage of the gust front, the wind maximum and convergence fluctuation descended to the near-surface . The northwest high wind maximum was coherent with the strong downdraft. After 21:12, gust front 1 disappeared in southeastern Hebei province.

\subsection{Gust front 2}

\subsubsection{The evolution stage (20:24-21:12)}

The convective storm A moved to the border between southern Tianjin and Hebei, the storm cell B to the rear of A travel direction developed into bow echo(Figure 3), The whole gale of $26.0 \mathrm{~m} \cdot \mathrm{s}^{-1}$ in Qingxian occurred at the apex of the bow echo. On the southeast flank of the moving direction of storm cell $\mathrm{B}$ emerged gust front 2 , of which maximum wind was less than $18.0 \mathrm{~m} \cdot \mathrm{s}^{-1}$ at this stage.

\subsubsection{The mature stage (21:12-22:00)}

The convective systems further developed into bow echo(BE), the intensity of thunderstorm high reached $1007.5 \mathrm{hPa}$, and the corresponding center of cold pool was $18{ }^{\circ} \mathrm{C}$ (Figure 2e). The intensity of the high pressure and the cold pool reached the maximum during the entire process. The storm cell B moved southeastward and approached cell A. The two cells merged into the inverted-Y echo, the outflow boundary in the echo adjacent area caused the disastrous 10 grade disastrous wind of $24.9 \mathrm{~m} \cdot \mathrm{s}^{-1}$ in Huanghua station. As seen from the radar echo observation, the string or narrow belt weak echo along the outflow boundary was not obvious when mixed with ground clutter or clear air echo ${ }^{[14]}$.

Different from gust front 1 , during the mature stage, downdraft dominated the boundary layer of gust front 2 whose maximum was around $900 \mathrm{~m}$ reaching $0.8 \mathrm{~m} \cdot \mathrm{s}^{-1}$. Northeasterly was under $700 \mathrm{~m}$, and above $700 \mathrm{~m}$ was 
southwesterly. As the strong echo passed Huanghua, it switched into northerly flow in the boundary layer and lower troposphere, and the maximum wind above 16 $\mathrm{m} \cdot \mathrm{s}^{-1}$ emerged under $900 \mathrm{~m}$. Gust front 2 in front of the bow echo brought 9 grade wind of $21.0 \mathrm{~m} \cdot \mathrm{s}^{-1}$ to Mengcun. Compared to the high wind initiated by the outflow boundary which did not split from the main body, the intensity of high wind associated with the gust front was relatively weak (Table 1). The maximum pressure gradient and temperature gradient along the gust front were $13.2 \mathrm{hPa} \cdot(10 \mathrm{~km})^{-1}$ and $2.5{ }^{\circ} \mathrm{C} \cdot(10 \mathrm{~km})^{-1}$, respectively.

\subsubsection{The dissipating stage (22:00-23:00)}

After 22:00, the left branch of the inverted-Y echo dissipated due to the vanishing of surface convergence line, the inverted-Y echo structure faded away. The wind related to gust front 2 decelerated significantly, the surface maximum velocity was below $17 \mathrm{~m} \cdot \mathrm{s}^{-1}$, and the pressure and temperature gradients weakened. The gust front dissipated accompanied by the system moved eastward to the sea around 23:00.

Table 1. Disastrous high wind characteristics in the representative stations of Tianjin-Hebei region

\begin{tabular}{|c|c|c|c|}
\hline \multirow{2}{*}{$\begin{array}{c}\text { Causes of disastrous } \\
\text { wind }\end{array}$} & $\begin{array}{c}\text { Gust } \\
\text { front } 1\end{array}$ & $\begin{array}{c}\text { In main } \\
\text { body }\end{array}$ & $\begin{array}{c}\text { Off } \\
\text { main } \\
\text { body }\end{array}$ \\
\hline Representative stations & Xiqing & $\begin{array}{c}\text { Huanghu } \\
\text { a }\end{array}$ & $\begin{array}{c}\text { Mengcu } \\
\mathrm{n}\end{array}$ \\
\hline Wind intensity $\left(\mathrm{m} \cdot \mathrm{s}^{-1}\right)$ & 17.0 & 24.9 & 21.0 \\
\hline Occurrence time & $18: 23$ & $21: 28$ & $21: 42$ \\
\hline $\begin{array}{c}\text { Maximum descending } \\
\text { velocity in boundary } \\
\text { layer }\left(\mathrm{m} \cdot \mathrm{s}^{-1}\right)\end{array}$ & 0.4 & 0.8 & 0.7 \\
\hline $\begin{array}{c}\text { The height occurred } \\
\text { maximum downdraft }(\mathrm{m})\end{array}$ & 270 & 870 & 990 \\
\hline $\begin{array}{c}\text { Time of the maximum } \\
\text { downdraft }\end{array}$ & $18: 12$ & $21: 18$ & $21: 24$ \\
\hline
\end{tabular}

\section{Boundary layer characteristics of gust front}

The Tianjin Tower in the boundary layer recorded the variations of synoptic elements during this gust front with high wind process, all the data were 1-min averaged with good quality. Gust front 1 affected the entire level of the front tower with the southerly not exceed $5.5 \mathrm{~m} \cdot \mathrm{s}^{-1}$ 。

At 18:15, fluctuations first emerged at $20 \mathrm{~m}$ and $120 \mathrm{~m}$ (Figure 3a), leading the emergence of disastrous high wind by 8 minute. At 18:24, the wind over the entire tower switched to the northerly, wind speed under $40 \mathrm{~m}$ accelerated rapidly with the velocity of $8.5 \mathrm{~m} \cdot \mathrm{s}^{-1}$ at $30 \mathrm{~m}$. At 18:25, maximum variations of cooling center with $3.1{ }^{\circ} \mathrm{C} \cdot \mathrm{min}^{-1}$ and wind velocity with $7.2 \mathrm{~m} \cdot(\mathrm{s} \bullet \mathrm{min})^{-1}$ occurred at $30 \mathrm{~m}$ and $60 \mathrm{~m}$, respectively. Afterward the high wind level lifted. Surface instantaneous maximum high wind of $8.1 \mathrm{~m} \cdot \mathrm{s}^{-1}$ occurred at 18:30 while the wind at lower tower level decelerated and mid-high level wind accelerated above $60 \mathrm{~m}$. At 18:39, the wind velocity reached $15.5 \mathrm{~m} \cdot \mathrm{s}^{-1}$ at $220 \mathrm{~m}$.
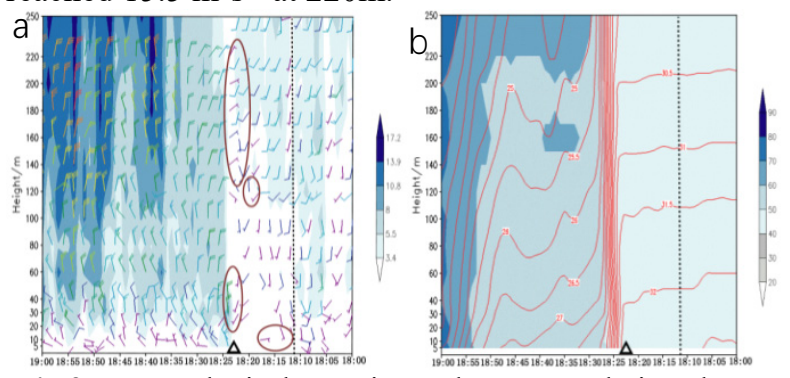

Fig.3. Meteorological per minute elements evolution observed by Tianjin tower at 18:00-19:00 10 June 2016 (a) shading: wind speed (units: $\mathrm{m} \bullet \mathrm{s}-1$ ), wind-direction shaft; time interval:2 min; brown ellipses denote convergence perturbation. (b)shading: relative humidity(units:\%), contours: temperature(units: ${ }^{\circ} \mathrm{C}$ ), denote the moment with maximum wind speed, black dashed lines denote the time when the gust front passed by

Based on the analysis above, the conceptual diagram of the vertical structure with the two gust fronts in the boundary layer was built (Figure 4). During the evolution stage, the vertical velocities of the two gust fronts were of little difference. Gust front 1 and 2 were associated with surface southwesterly and northeasterly, respectively. During the mature stage, updraft was at mid-high level of the boundary layer associated with gust front 1 while downdraft was dominant in the boundary layer related to gust front 2, this was one of the reasons why surface wind was stronger as caused by gust front 2 than gust front 1 . During the dissipating stage, northerly dominated boundary layer associated with the 2 gust fronts. Additionally, extremely strong wind exceeded $20 \mathrm{~m} \cdot \mathrm{s}^{-1}$ was at middle level.

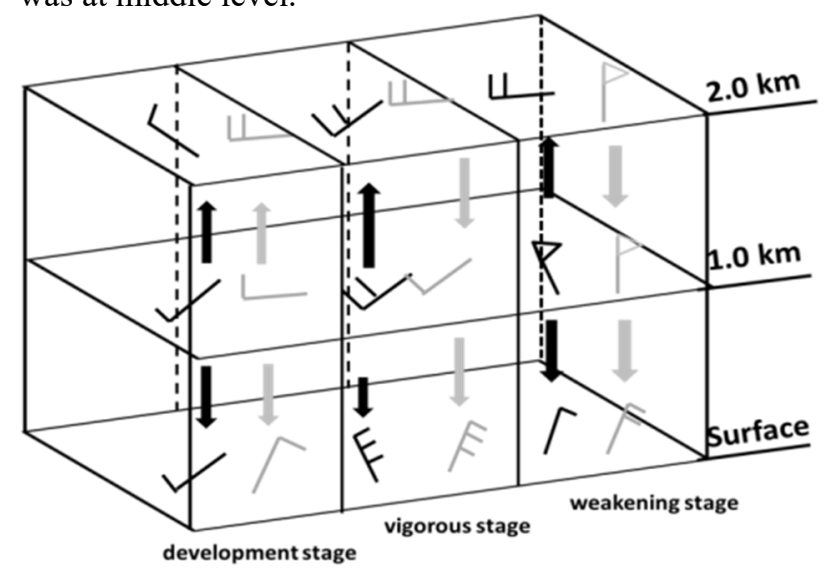

Fig.4. The conceptual diagram of vertical structure of the gust front on 10 June 2016(The 3D structures of horizontal and vertical velocities. Black represent gust front 1 and grey represent gust front 2 . The upward and downward arrows denote updraft and downdraft, respectively)

\section{Conclusions and discussion}

Based on Doppler radar 3D-composited reflectivity data, wind profiler radar data, boundary layer Tianjin tower data and intensified automatic surface observation data in Beijing-Tianjin-Hebei region, the evolution of the 
boundary layer related to two successive gust front processes in the evening of 10 June 2016 and the intensity of the related disastrous high wind were analyzed. The main conclusions are as follows:

(1) The intensity was not proportional to the last time of the instantaneous wind caused by the gust front. The duration of the gust front in front of the bow echo was the shortest while the wind intensity caused by the gust front was the strongest. To the same storm cell, the wind intensity caused by the outflow boundary in the main body was stronger than the wind caused by the gust front. The intensity of the disastrous high wind was related to the maximum downdraft in the boundary layer and the associated height. The stronger the maximum downdraft and the lower the level, the stronger the disastrous high wind was.

(2) It was indicated by the tower data, as the approaching of the gust front, it emerged convergence fluctuations at low $(20 \mathrm{~m})$ and middle $(120 \mathrm{~m})$ levels of the tower, leading the emergence of disastrous high wind by 8 minutes. When the gust front passed over, the wind direction over all levels of the tower switched into northerly. The maximum variations of cooling and the wind velocity basically kept in pace with each other. The maximum cool reached $3.1^{\circ} \mathrm{C} \cdot \mathrm{min}^{-1}$, and the drastic changes of velocity and temperature lasted for 2 minutes and 4 minutes, respectively.

\section{Acknowledgment}

Supported by the National Natural Science Foundation of China(41675046,40975026)

\section{References}

1. Harrison S J, Mecikalski J R, Knupp K R. Analysis of outflow boundary collisions in north-central Alabama. Wea. Forecasting, 24,6 (2009)

2. Quan Wanqing, Xu Xin, Wang Yuan. Observation of a straight-line wind case caused by a gust front and its associated fine-scale structures. J Meteor Res, 28,6 (2014)

3. Wu Juxiu, Zhou Qing, Yang Chuanfeng, et al. Analysis of the weather radar products characteristics of the gust front and the wind after the gust front on 14 July 2015. Plateau Meteor, 36,4 (2017)
4. Wu Maifeng, Ji Qing, Wu Weigang. A mesoscale ananlysis of a gust front weather process caused by fore-trough dry convection. Plateau Meteor, 36,3 (2017)

5. Wang Yan, Yu Lili, Zhu Nannan, et al. Sea breeze front in Bohai Bay and thunderstorm weather. Plateau Meteor, 30,1 (2011a)

6. Wang Yan, Yu Lili, Li Yanwei, et al. The role of boundary layer convergence line in initiation of severe weather events. J Appl Meteor Sci, 22,6 (2011b)

7. Wang Yan, Liu Yiwei, Sun Xiaolei. Analyzing the vertical wind shear characteristic of a severe rainfall using wind-profile radar data.Torrential Rain and Disasters,36,2 (2017)

8. Tu Xiaoping, Yao Risheng, Qi Liangbo, et al. Analysis on characteristics of a damage wind case in Doppler radar and boundary layer across northern Zhejiang Province. Plateau Meteor, 33,6 (2014)

9. Xu Changyi, Yi Xiaoyuan, Duan Liyao, et al. Synthetic applications of multi-data to weak precipitation thunderstorm accompanied by disastrous winds in Tianjin. Meteor Sci \& Tec, 45,2(2017)

10. Gao Xiaomei, Yu Xiaoding, Wang Lingjun, et al. Characteristics of environmental parameters for classified severe convective weather in central area of Shangdong Province. Acta Meteor.Sinica, 76,2 (2018)

11. Wu Zhifang, Pang Guqian, He Hanqing et al. Comparative analysis of environmental conditions and structural features for the left-moving supercell and the supercell in squall line in April 2012 Guangdong. Meteor Mon, 40,6 (2014)

12. Yang Xinlin, Sun Jianhua. Organizational modes of severe wind-producing convective systems over North China..Adv. Atmos. Sci.,35,5 (2018)

13. Wang Yan, Gao Shouting, Liang Zhaoming. Analysis on the observation and simulation of thunderstorms triggered by sea breeze front in Bohai Bay. Plateau Meteor,33,3 (2014)

14. Chen Mingxuan, Xiao Xian, Gao Feng. Dynamical effect of outflow boundary on localized initiation and enhancement of severe convection over Beijing-Tianjin-Hebei region. Chinese Journal of Atmosperic Sciences, 41,5 (2017) 